\title{
Sebaran Cemaran Hg di Kawasan Pertambangan Emas Rakyat Menggunakan Metode Inverse Distance Weight
}

\author{
Esthi Kusdarini ${ }^{1^{*}}$, Abd. Malik $^{2}$, Lakon Utamakno ${ }^{3}$, Agus Budianto ${ }^{4}$ \\ ${ }^{1,2,3}$ Teknik Pertambangan, Institut Teknologi Adhi Tama Surabaya \\ ${ }^{4}$ Teknik Kimia, Institut Teknologi Adhi Tama Surabaya \\ *Koresponden E-mail: esti@itats.ac.id
}

(Diterima 20 Desember 2020|Disetujui 28 Mei 2021 |Diterbitkan 17 Juli 2021)

\begin{abstract}
Gold mining on mining communities supports economic life for the societies. On the other hands, these activities are not only support the economic but also give bad effects to the environment. Some people are still using amalgamation process to gold ore process which has the potential to spread Hg concentration in the main area. Spatial distribution of Hg concentration was found in this study. The purpose of this research was identifying the contamination of $\mathrm{Hg}$ concetration in three villages of society's mining gold areas in Kertajaya Sukabumi, West Java. Those three villages were Cigadog Village, Pondok Tilu Citamiang Village, and Kiara 2 Village. Hg concentration distribution map was obtained several samples which were taking 6 soil samples in Cigadog village, 5 soil samples from Pondok Tilu Citamiang Village, and 4 soil samples in Kiara 2 Village. Those samples were analysed for Hg concentration using AAS (Atomic Absorption Spectrophotometer) method. Inverse Distance Weight method was used as Data processing and it was helped by ArcGIS software. The result showed that soil samples from Cigadong village contained Hg concentration of $0.28-2.84$ ppm, 83\% samples were critically polluted, and the contaminated areas were 5.888 hectares. Whilst, soil samples from Pondok Tilu Citamiang Village contained Hg concentration of $0.14-1.26 \mathrm{ppm}, 80 \%$ samples were critically polluted, and the polluted areas were $1.476 \mathrm{Ha}$. Then, soil samples from Kiara 2 Village contained Hg concentration of 0.67-6.19 ppm, 100\% samples were critically polluted, and the contaminated area was 0.040 hectare. The findings of the contaminated area and the pollutant level in mining societies in Kertajaya Village, Sukabumi could be used as initial input for the efforts to restore the Hg polluted environment.
\end{abstract}

Keywords: Amalgamation, ArcGIS, Inverse distance weight, Hg pollution, Gold mining on mining community

\section{PENDAHULUAN}

Logam berat apabila terikut dalam makanan atau minuman yang dikonsumsi maka akan terakumulasi dalam tubuh makhluk hidup (Kusdarini et al., 2017; Kusdarini \& Budianto, 2018; Kusdarini et al., 2018; Kusdarini et al., 2018; Kusdarini et al., 2018; Kusdarini et al., 2019). Hg masuk tubuh melalui tanaman dan air tercemar yang dikonsumsi. Manusia yang terpapar $\mathrm{Hg}$ dapat mengalami resiko tinggi membahayakan kesehatannya (Khan et al., 2020; Khanam et al., 2020). Salah satu penyebab logam $\mathrm{Hg}$ mencemari tanah adalah proses pengolahan bahan tambang pada pertambangan konvensional.

Pertambangan emas rakyat (PERA) termasuk pertambangan konvensional. PERA tumbuh menjamur di beberapa daerah, antara lain Papua, Pulau Sumbawa, Sumatera Utara, Jawa Barat, Jawa Tengah, Jawa Timur, dan Maluku. Pertumbuhan yang cepat ini disebabkan pertambangan emas rakyat merupakan mata pencaharian yang menarik bagi masyarakat setempat. Aktifitas ini menopang kehidupan ekonomi mereka. Meskipun PERA menopang kehidupan ekonomi rakyat, kegiatan ini juga berpotensi menimbulkan dampak negatif, yaitu pencemaran terhadap lingkungan (Adinata et al., 2015; HZ et al., 2018; Sitorus et al., 2020). Hal ini disebabkan sebagian masyarakat masih mengolah bijih emas dengan menggunakan metode amalgamasi dengan logam Hg (mercuri). Mercuri termasuk jenis logam berat yang dapat terlepas ke lingkungan pada proses amalgamasi. Hal ini menimbulkan pencemaran tanah dan air di area penambangan (BaptistaSalazar \& Biester, 2019; Ning et al., 2020).

Penambangan emas rakyat di Desa Kertajaya, Kecamatan Simpenan, Kabupaten Sukabumi, Jawa Barat diawali dengan membuat sumuran, kemudian menggali batuan/bijih emas menggunakan palu dan pahat. Selanjutnya batuan diangkut ke permukaan bumi menggunakan bak/jerigen yang ditarik katrol. Batuan diolah masyarakat setempat menggunakan metode amalgamasi dan sianidasi. Dari kedua metode ini, metode amalgamasi lebih berpotensi mencemari lingkungan karena penggunaan merkuri untuk proses pengolahan batuan.

Usaha mitigasi penggunaan mercuri telah diupayakan oleh Pemerintah. Pemerintah Indonesia 
telah menerbitkan Undang-Undang Nomor 11 Tahun 2017 (Sumarjono \& Utamakno, 2019). Reduksi pencemaran lingkungan oleh logam mercuri dapat dilakukan dengan mengurangi atau melarang penggunanan metode almagamasi. Pemerintah memberikan metode alternatif dalam pengolahan biji emas dengan metode sianidasi. Metode sianidasi ini lebih murah dan aman. Metode sianidasi membutuhkan karbon aktif baik berasal dari kayu kayuan atau batubara (Kusdarini et al., 2017; Budianto et al., 2019).

Membantu usaha pemerintah untuk mengurangi daerah tercemar dapat dilakukan dengan proses pemulihan. Langkah awal proses pemulihan dapat dilakukan dengan pemetaan lokasi-lokasi yang tercemar Hg. Beberapa penelitian telah dilakukan untuk memetakan lokasi pencemaran di kawasan pertambangan rakyat, namun hasil penelitian masih berupa data data, belum digambarkan dalam peta spasial (Adinata et al., 2015; Kurniawan \& Mustikasari, 2019; Nugroho et al., 2019; Putra et al., 2019). Penelitian ini bertujuan untuk menggambarkan secara spasial pencemaran $\mathrm{Hg}$ dan menjelaskan tingkat pencemaran $\mathrm{Hg}$ di kawasan pertambangan rakyat menggunakan metode Inverse Distance Weight dengan bantuan software ArcGIS.

\section{BAHAN DAN METODE}

\section{Lokasi Penelitian}

Lokasi penelitian di kawasan pertambangan emas rakyat, Desa Kertajaya, Kecamatan Simpenan, Kabupaten Sukabumi, Jawa Barat (Kampung Cigadog, Kampung Pondok Tilu, dan Kampung Kiara 2) (Gambar 1).

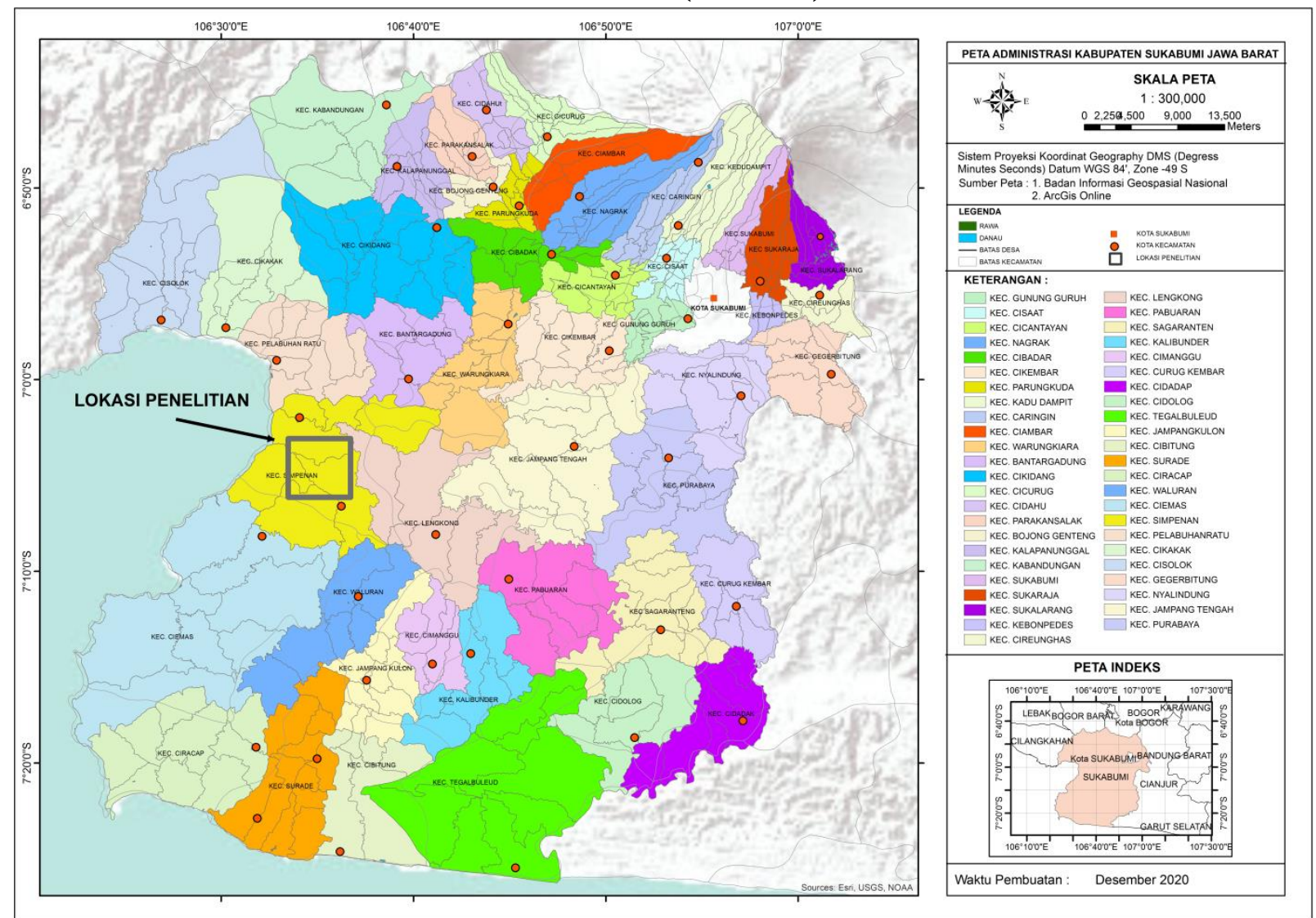

Gambar 1. Lokasi Penelitian

\section{Pengumpulan Data}

Langkah awal penelitian adalah mengambil sampel tanah. Pengambilan sampel dilakukan secara acak berdasarkan wilayah kampung (Cluster Random Sampling) (Kusdarini et al., 2020). Sebanyak 15 sampel diambil dari 3 desa, yaitu Kampung Cigadog (6 sampel: L_01-L_06), Kampung Pondok Tilu (5 sampel: L_07-L_11), dan Kampung Kiara 2 (4 sampel:
L_12-L_15). Koordinat lokasi pengambilan sampel adalah disajikan pada Tabel 1.

Pencatatan koordinat menggunakan GPS Garmin tipe etrex 10. Selanjutnya dilakukan pengeboran sedalam 20-30 cm menggunakan bor tangan, pengambilan sampel tanah dan penyimpanan sampel tanah ke dalam kantung. 
Tabel 1. Koordinat Lokasi Pengambilan Sampel

\begin{tabular}{|c|c|c|}
\hline No Sampel & Latitude & Longitude \\
\hline $\bar{L}$ L_01 & $7^{\circ} 5^{\prime} 45.159^{\prime \prime} \mathrm{S}$ & $106^{\circ} 35^{\prime} 34.981^{\prime \prime E}$ \\
\hline L_02 & $7^{\circ} 5^{\prime} 45.224^{\prime \prime S}$ & $106^{\circ} 35^{\prime} 35.046^{\prime \prime E}$ \\
\hline L_03 & $7^{\circ} 5^{\prime} 38.989^{\prime \prime S}$ & $106^{\circ} 35^{\prime} 40.043^{\prime \prime} \mathrm{E}$ \\
\hline L_04 & $7^{\circ} 5^{\prime} 36.147 " \mathrm{~S}$ & $106^{\circ} 35^{\prime} 33.255^{\prime \prime} \mathrm{E}$ \\
\hline L_05 & $7^{\circ} 5^{\prime} 36.083^{\prime \prime S}$ & $106^{\circ} 35^{\prime} 33.157^{\prime \prime E}$ \\
\hline L_06 & $7^{\circ} 5^{\prime} 36.148^{\prime \prime S}$ & $106^{\circ} 35^{\prime} 33.125^{\prime \prime} \mathrm{E}$ \\
\hline L_07 & $7^{\circ} 6^{\prime} 52.346^{\prime \prime S}$ & $106^{\circ} 37^{\prime} 37.421^{\prime \prime E}$ \\
\hline L_08 & $7^{\circ} 6^{\prime} 51.922^{\prime \prime S}$ & $106^{\circ} 37^{\prime}-7.615^{\prime \prime} \mathrm{E}$ \\
\hline L_09 & $7^{\circ} 6^{\prime} 50.59 " \mathrm{~S}$ & $106^{\circ} 37^{\prime} 45.888^{\prime \prime} \mathrm{E}$ \\
\hline L_10 & $7^{\circ} 6 ' 50.558^{\prime \prime} \mathrm{S}$ & $106^{\circ} 37^{\prime} 45.953^{\prime \prime} \mathrm{E}$ \\
\hline L_11 & $7^{\circ} 6 ' 50.492 " \mathrm{~S}$ & $106^{\circ} 37^{\prime} 46.018^{\prime \prime} \mathrm{E}$ \\
\hline L_12 & $7^{\circ} 7^{\prime} 49.285^{\prime \prime S}$ & $106^{\circ} 37^{\prime} 17.318^{\prime \prime} \mathrm{E}$ \\
\hline L_13 & $7^{\circ} 7^{\prime} 50.229^{\prime \prime} \mathrm{S}$ & $106^{\circ} 37^{\prime} 17.55^{\prime \prime} \mathrm{E}$ \\
\hline L_14 & $7^{\circ} 7^{\prime} 50.327^{\prime \prime S}$ & $106^{\circ} 37^{\prime} 17.387^{\prime \prime} \mathrm{E}$ \\
\hline L_15 & $7^{\circ} 7^{\prime} 50.198^{\prime \prime S}$ & $106^{\circ} 37^{\prime} 17.061^{\prime \prime E}$ \\
\hline
\end{tabular}

\section{Pengolahan dan Analisa Data}

Pengujian konsentrasi $\mathrm{Hg}$ pada sampel menggunakan metode spektrofotometri di Laboratorium Baristand Surabaya. Alat yang digunakan untuk pengujian adalah corong, neraca analitik, cawan platina, beaker glass, labu ukur, pipet ukur, pipet volume, furnace, desikator, Atomic Absorption Spectrophotometry (AAS) bermerek Shimadzu. Bahan yang digunakan untuk pengujian AAS adalah sampel tanah, larutan $\mathrm{HNO}_{3} \mathrm{pa}, \mathrm{H}_{2} \mathrm{SO}_{4} \mathrm{pa}$, larutan $\mathrm{H}_{2} \mathrm{O}_{2} 30 \%$, larutan standar $\mathrm{Hg}$, aquades, dan kertas whatman. Data koordinat lokasi sampel dan kandungan $\mathrm{Hg}$ diolah menggunakan metode Inverse Distance Weight (IDW) dan software ArcGIS sehingga diperoleh peta spasial pencemaran $\mathrm{Hg}$ di lokasi penelitian. IDW adalah salah satu metode interpolasi pada wilayah yang tidak terukur sehingga diperoleh sebaran nilai pada wilayah tersebut. Hasil interpolasi lebih serupa dengan data sampel yang berjarak lebih dekat daripada yang lebih jauh. Metode ini menganut asumsi bahwa setiap titik input mempunyai pengaruh lokal yang semakin kecil terhadap jarak (Mierlo et al., 2021). Selanjutnya dari peta spasial diperoleh data luas area tercemar $\mathrm{Hg}$ dan tingkat pencemarannya.

\section{HASIL DAN PEMBAHASAN}

\section{Kandungan Hg}

Kandungan $\mathrm{Hg}$ dari 15 sampel tanah disajikan pada Tabel 2, Tabel 3, dan Tabel 4.

Tabel 2. Kandungan Hg Sampel Tanah Kampung Cigadog

\begin{tabular}{cccc}
\hline Kode Sampel & $\operatorname{Hg}($ ppm $)$ & $\begin{array}{c}\text { Kedalaman Sampel } \\
(\mathrm{cm})\end{array}$ & $\begin{array}{c}\text { Pencemaran } \\
\text { Hg* }^{*}\end{array}$ \\
\hline L_01 & 3,84 & 30 & Kritis \\
L_02 & 1,26 & 30 & Kritis \\
L_03 & 1,09 & 30 & Kritis \\
L_04 & 0,87 & 30 & Kritis \\
L_05 & 0,41 & 30 & Kritis \\
L_06 & 0,28 & 30 & Normal \\
\hline
\end{tabular}

*Alloway, 1990 
Tabel 3. Kandungan Hg Sampel Tanah Kampung Pondok Tilu

\begin{tabular}{cccc}
\hline Kode Sampel & $\operatorname{Hg}(\mathrm{ppm})$ & $\begin{array}{c}\text { edalaman Sampel } \\
(\mathrm{cm})\end{array}$ & $\begin{array}{c}\text { Pencemaran } \\
\mathrm{Hg}^{*}\end{array}$ \\
\hline L_07 & 1,26 & 30 & Kritis \\
L_08 & 0,85 & 30 & Kritis \\
L_09 & 0,76 & 20 & Kritis \\
L_10 & 0,57 & 20 & Kritis \\
L_11 & 0,14 & 20 & Normal \\
\hline
\end{tabular}

*Alloway, 1990

Tabel 4. Kandungan Hg Sampel Tanah Kampung Kiara 2

\begin{tabular}{cccc}
\hline Kode Sampel & Hg(ppm) & $\begin{array}{c}\text { Kedalaman Sampel } \\
(\mathrm{cm})\end{array}$ & Pencemaran $\mathrm{Hg}^{\star}$ \\
\hline L_12 & 6,19 & 30 & Kritis \\
L_13 & 4,62 & 30 & Kritis \\
L_14 & 1,31 & 30 & Kritis \\
L_15 & 0,67 & 30 & Kritis \\
\hline
\end{tabular}

*Alloway, 1990

Penelitian sebelumnya menjelaskan bahwa konsentrasi merkuri dalam tanah sebesar 0,01-0,3 $\mathrm{mg} / \mathrm{L}$ tergolong normal, sedangkan 0,3-0,5 mg/L tergolong kritis (Alloway, 1990). Kandungan Hg pada sampel tanah dari Kampung Cigadog 83\% tergolong kritis dan $17 \%$ tergolong normal. Kandungan $\mathrm{Hg}$ pada sampel tanah dari Kampung Pondok Tilu 80\% tergolong kritis dan 20\% tergolong normal. Sedangkan kandungan $\mathrm{Hg}$ pada sampel tanah dari Kampung Kiara 2 seluruhnya tergolong kritis. Selanjutnya peta sebaran $\mathrm{Hg}$ disajikan pada Gambar 2 (Kampung Cigadog), Gambar 3 (Kampung Pondok Tilu), dan Gambar 4 (Kampung Kiara 2).

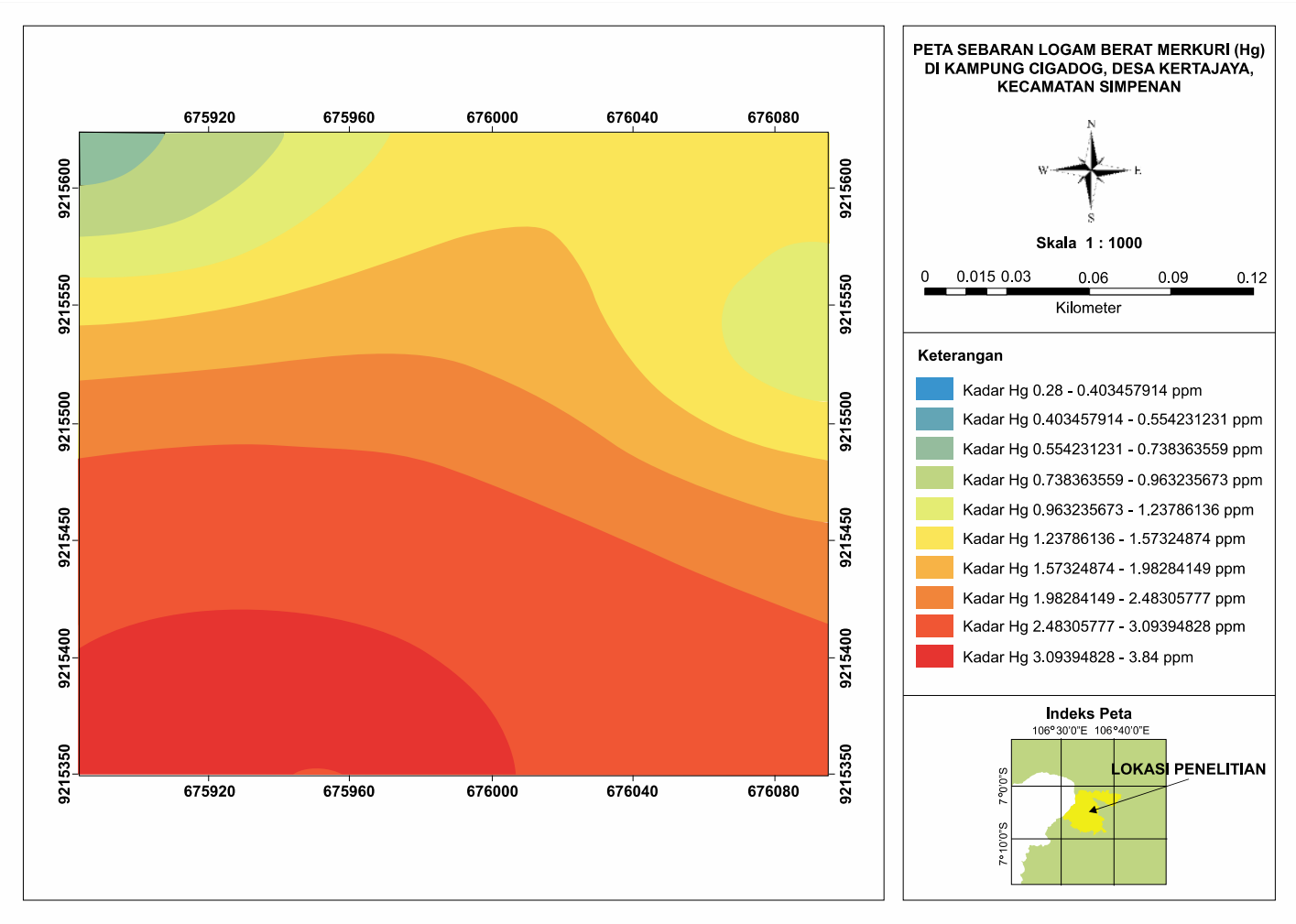

Gambar 2. Peta sebaran Hg di Kampung Cigadog 


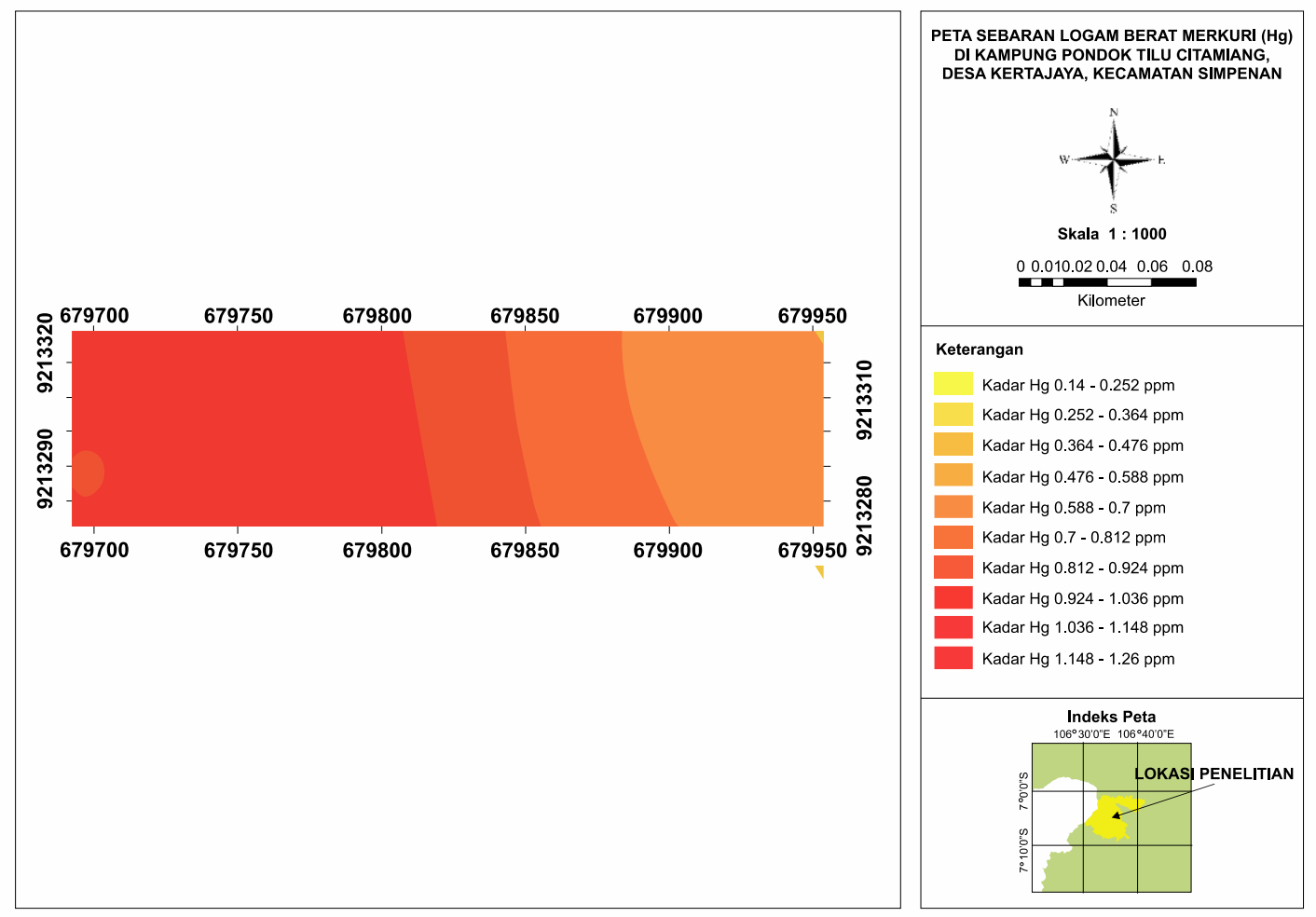

Gambar 3. Peta sebaran Hg di Kampung Pondok Tilu
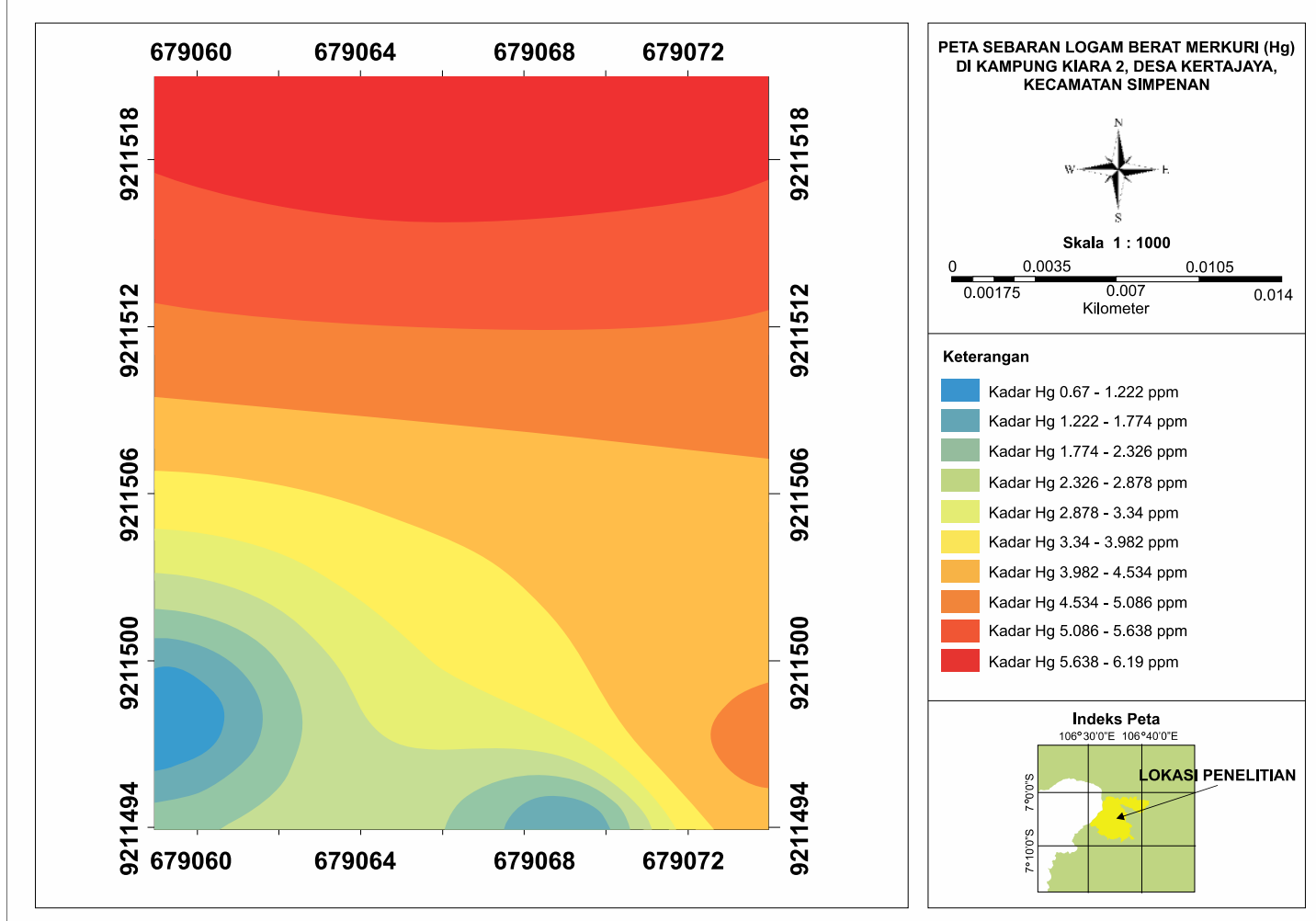

Gambar 4. Peta sebaran Hg di Kampung Kiara 2

Gambar 2 sampai Gambar 4 menunjukkan bahwa pencemaran pada tanah di area pertambangan emas rakyat di Kampung Cigadog, Pondok Tilu, dan Kiara 2 lebih dari $80 \%$ termasuk kritis (lebih besar dari $0,3 \mathrm{ppm})$. Penelitian ini sangat penting karena menemukan fakta yang menarik bahwa pencemaran $\mathrm{Hg}$ pada tanah di area pertambangan emas rakyat termasuk dalam kategori berat atau kritis. Pencemaran $\mathrm{Hg}$ di lokasi penelitian melengkapi penelitian sebelumnya yang menjelaskan bahwa di kawasan ini 
juga terjadi pencemaran sianida $(\mathrm{CN})$ pada tanah dalam kategori kritis dan pencemaran pada air sumur dan air sungai dalam kategori ringan (Adinata et al., 2015). Tingkat pencemaran Hg pada kawasan pertambangan emas rakyat bisa bervariasi di berbagai daerah. Hal ini dibuktikan dari penelitian lain yang menjelaskan bahwa pencemaran air sungai di area pertambangan emas rakyat di daerah Banyumas, Jawa Tengah termasuk dalam kategori ringan (Putra et al., 2019). Selanjutnya pencemaran $\mathrm{Hg}$ di bagian hilir sungai Puyango-Tumbes (Equador, Peru) juga terjadi akibat adanya pertambangan emas rakyat daerah tersebut (Schudel et al., 2018) . Oleh karena adanya potensi perbedaan tingkat pencemaran pada tanah, air sumur, dan air permukaan, maka penelitian ini penting dan sangat menarik untuk dikembangkan sehingga diperoleh data pencemaran $\mathrm{Hg}$ pada air sumur dan air sungai di kawasan ini mengingat sebagian masyarakat masih menggunakan air sumur dan air sungai untuk memenuhi kebutuhan air bersih (Hertisa, 2018; HZ et al., 2018).

Hasil penelitian ini juga mendukung fakta dari penelitian lain yang menjelaskan bahwa tanaman padi pada suatu area pertambangan emas telah tercemar oleh Hg. Kondisi ini dapat membahayakan kesehatan manusia yang mengkonsumsi padi tersebut (Khan et al., 2020; Khanam et al., 2020). Tanaman padi mudah mengakumulasi merkuri terutama metil merkuri $(\mathrm{MeHg}$ ) dengan toksisitas tinggi (Wang et al., 2020). Oleh karena itu, ada kebutuhan mendesak untuk menemukan teknik remediasi tanah yang dapat menjamin produksi pertanian dan melindungi kesehatan manusia di daerah yang terkontaminasi $\mathrm{Hg}$ ini. Dalam penelitian ini, montmorilonit (Mont) dan batu medis (Med) dimodifikasi dengan bahan berbasis tiol (-SH) dan kitosan untuk mendapatkan adsorben mineral lempung yang dimodifikasi.

\section{SIMPULAN}

Tiga kampung di kawasan pertambangan rakyat, Desa Kertajaya, Sukabumi, Jawa Barat telah tercemar Hg. Lima dari enam sampel tanah dari Kampung Cigadog tercemar $\mathrm{Hg}$ dengan kategori kritis $(0,41-3,84 \mathrm{mg} / \mathrm{L})$. Empat dari lima sampel tanah dari Kampung Pondok Tilu tercemar $\mathrm{Hg}$ dengan kategori kritis $(0,57-1,26 \mathrm{mg} / \mathrm{L})$. Sedangkan seluruh sampel tanah dari Kampung Kiara 2 tercemar $\mathrm{Hg}$ dengan kategori kritis $(0,67-6,19 \mathrm{mg} / \mathrm{L})$.

Penelitian ini sangat penting untuk merencanakan pemulihan tanah tercemar $\mathrm{Hg}$. Hal ini mengingat lebih dari $80 \%$ sampel tanah tercemar $\mathrm{Hg}$ dengan kategori kritis. Perencanaan pemulihan tanah tercemar Hg memerlukan kerjasama yang baik antar stakeholder, terutama jika dikomando oleh Kementerian Energi dan Sumber Daya Mineral Republik Indonesia wilayah setempat.

\section{UCAPAN TERIMAKASIH}

Penelitian ini didukung oleh Loka Uji Teknik Penambangan Jampang Kulon - LIPI dan Jurusan Teknik Pertambangan Institut Teknologi Adhi Tama Surabaya.

\section{DAFTAR PUSTAKA}

Adinata, D. Y., Vie, A. R. C. D. C., \& Kusdarini, E. (2015). Identifikasi Limbah Pengolahan Emas Dan Kualitas Air di Sekitar Penambangan Emas Rakyat Jampang Kulon, Desa Kertajaya, Kabupaten Sukabumi, Jawa Barat. Seminar Nasional Sains dan Teknologi Terapan III. Surabaya: Institut Teknologi Adhi Tama Surabaya, 503-510.

Alloway. (1990). Soil processes and behaviour of metals. In Alloway [Ed.] Heavy Metals in Soils. New York: Blackie Glasgow and London Halsted Press. John Wiley and Sons.Inc.

Baptista-Salazar, C. \& Biester, H. (2019). The role of hydrological conditions for riverine $\mathrm{Hg}$ species transport in the Idrija mining area. Environmental Pollution, 247, 716-724. https://doi.org/10.1016/j.envpol.2019.01.109.

Budianto, A., Kusdarini, E., \& Effendi, S. S. W. (2019). The Production of Activated Carbon from Indonesian Mangrove Charcoal. IOP Conference Series: Materials Science and Engineering. DOI: 10.1088/1757-899X/462/1/012006.

Hertisa, R. (2018). Konsumsi Air Kajian Kelayakan Air Sumur Perumahan Tipe 36 di Kota Pekanbaru. Dinamika Lingkungan Indonesia, 5(1), 1-11.

Khan, A. Z., Khan, S., Khan, M. A., Alam, M., \& Ayaz, T. (2020). Biochar reduced the uptake of toxic heavy metals and their associated health risk via rice (Oryza sativa L.) grown in Cr-Mn mine contaminated soils. Environmental Technology \& Innovation, 17. https://doi.org/10.1016/j.eti.2019.100590.

Khanam, R., Kumar, A., Nayak, A. K., Shahid, Md., Tripathi, R., Vijayakumar, S., Bhaduri, D., Kumar, U., Mohanty, S., Panneerselvam, P., Chatterjee, D., Satapathy, B. S., \& Pathak, H. (2020). Metal(loid)s (As, Hg, Se, $\mathrm{Pb}$ and $\mathrm{Cd}$ ) in paddy soil: Bioavailability and potential risk to human health. Science of The Total Environment, 699.

https://doi.org/10.1016/j.scitotenv.2019.134330.

Kurniawan, A. \& Mustikasari, D. (2019). Review: Mekanisme Akumulasi Logam Berat di Ekosistem Pascatambang Timah. Jurnal Ilmu Lingkungan, 17(3), 408-415.

Kusdarini, E., Suyadi, S., Yanuwiadi, B., \& Hakim, L. (2019). Analysis of Water Sources Availability and Water Quality in Dry and Rainy Season in Dry Land Areas, North Gresik, Indonesia. 
Pollution Research, 38(4), 58-65.

Kusdarini, E., Yanuwiadi, B., Hakim, L., \& Suyadi, S. (2020). Adoption Model of Water Filter by The Society of Lake Water Users in Dry Land Area, Gresik, East Java, Indonesia. International Journal on Advanced Science Engineering Information Technology, 10(5), 2089-2096.

Kusdarini, E. \& Budianto, A. (2018). Removal of Manganese from Well-Water on Pasuruan, East Java, Indonesia Using Fixed Bed Cation Exchanger and Prediction of Kinetics Adsorption. Indian Journal of Science and Technology, 11(23), 1-7.

Kusdarini, E., Budianto, A. \& Fitriawan, E. R. (2018). The Effect of Ag+ Ion Existence in The Cyanidation Process of Tailing of Cijiwa Gold Ore Process on Gold Recovery. International Journal of Applied Engineering Research, 13(15), 12111-12114.

Kusdarini, E., Budianto, A. \& Ghafarunnisa, D. (2017). Produksi Karbon Aktif dari Batubara Bituminus dengan Aktivasi Tunggal H3PO4, Kombinasi H3PO4-NH4HCO3, dan Termal. Reaktor, 17(2), 74-80. http://dx.doi.org/10.14710/reaktor.17.2.74-80.

Kusdarini, E., Budianto, A. \& Gingga, F. (2018). Recovery of Gold with AgNO 3 Pretreatment by Cyanidation at Heap Leaching Cijiwa Gold Ore Processing. Makara Journal of Science, 22(2), 7781.

Kusdarini, E., Purwaningsih, D. Y. \& Budianto, A. (2018). Adsorption of $\mathrm{Pb}^{2+}$ Ion in Water Well with Amberlite Ir $120 \mathrm{Na}$ Resin. Pollution Research, 37(4), 307-312.

Kusdarini, E., Purwaningsih, D. Y. \& Iqbal, M. (2017). Removal Pb ( II ) dari Air Sumur di Kota Pasuruan Menggunakan Proses Cation Exchanger. Seminar Nasional Sains dan Teknologi Terapan V, D-39-D-44.

Mierlo, C. van, Faes, M. G. R. \& Moens, D. (2021). Inhomogeneous interval fields based on scaled inverse distance weighting interpolation. Computer Methods in Applied Mechanics and Engineering, 373, 1-18. DOI:

https://doi.org/10.1016/j.cma.2020.113542.
Ning, Z., Liu, E., Yao, D., Xiao, T., Ma, L., Liu, Y., Li, H., \& Liu, C. (2020). Contamination, oral bioaccessibility and human health risk assessment of thallium and other metal(loid)s in farmland soils around a historic $\mathrm{Tl}-\mathrm{Hg}$ mining area. Science of The Total Environment. DOI: https://doi.org/10.1016/j.scitotenv.2020.143577.

Nugroho, U. C., Kushardono, D. \& Dewi, E. K. (2019). Identifikasi Kawasan Pertambangan Timah Menggunakan Data Satelit Sentinel - 1 dengan Metode Object Based Image Analysis (OBIA). Jurnal Ilmu Lingkungan, 17(1), 140-148.

Putra, D. M., Sungkowo, A. \& Muryani, E. (2019). Arahan Teknis Pengolahan Limbah Hasil Proses Amalgamasi untuk Menurunkan Kadar Merkuri di Desa Cihonje, Kecamatan Gumelar, Kabupaten Banyumas, Jawa Tengah. Lingkungan Kebumian, 2(1), 13-23.

Schudel, G., Miserendino, R. A., Veiga, M. M., Velasquez-Lopez, P. C., Lees, P. S. J., WinlandGaetz, S., Guimaraes, J. R. D., \& Bergquist, B. A. (2018). An investigation of mercury sources in the Puyango-Tumbes River: Using stable $\mathrm{Hg}$ isotopes to characterize transboundary $\mathrm{Hg}$ pollution. Chemosphere, 202, 777-787. DOI: https://doi.org/10.1016/j.chemosphere.2018.03.0 81.

Sitorus, S., Ilang, Y. \& Nugroho, R. A. (2020). Analisis kadar logam $\mathrm{Pb}, \mathrm{Cd}, \mathrm{Cu}$, As pada air, sedimen dan bivalvia di Pesisir Teluk Balikpapan. Dinamika Lingkungan Indonesia, 7(28), 89-94. DOI: 10.31258/dli.7.2.p 89-94.

Sumarjono, E. \& Utamakno, L. (2019). UndangUndang Nomor 11 Tahun 2017 sebagai Upaya Perlindungan dan Penyelamatan Lingkungan terhadap Bahaya Merkuri. Seminar Teknologi Kebumian dan Kelautan, 119-124.

Wang, Y., He., T., Yin, D., Han, Y., Zhou, X., Zhang, G, \& Tian, X (2020). Modified clay mineral: A method for the remediation of the mercury-polluted paddy soil. Ecotoxicology and Environmental Safety, 204. DOI:

https://doi.org/10.1016/j.ecoenv.2020.111121. 